International Journal of Language Education and Culture Review, Vol.3 (1) June 2017, 13 - 19.

Available online at http://journal.unj.ac.id/unj/index.php/ijlecr

DOI:doi.org/10.21009/IJLECR.031.02

\title{
POLITENESS SOCIETY REGENCY OF FOUR LAWANG
}

\author{
Idawati \\ Raden Fatah Palembang State Islamic University \\ idawati2015.iw@gmail.com
}

\begin{abstract}
This study aimed to describe in depth politeness of society of Empat Lawang district in South Sumatra. The focus of research is the politeness of society of Empat Lawang. Sub focus of research includes: politeness strategies, principles of cooperation, the function of politeness and civility in terms of cultural aspects. This research is ethnography of communication. Techniques and procedures for data collection is done by observation, recordings, transcripts, and interviews. Verify the validity of the data is done with credibility, transferability, dependability, and comfirmability. Data analysis was done by transcribing recordings data into written form, then analyzed based on situations, events, and communicative action. Based on data analysis found that politeness of society of Empat Lawang district bith formally and informally expressed through: (1) positive and negative politeness strategies in accordance with the model of politeness Brown and Levinson; (2) the application of the principles of cooperation in accordance with the model of Grice's speech, although still a violation of the maxim; (3) the function of language as a medium to achieve the purpose of communication through asking, offers, orders/errand, and refused functions; (4) The cultural aspect is manifested in the form of verbal and nonverbal communication.
\end{abstract}

Keywords: politeness, strategies, principles of cooperation, function, cultural aspects.

Language politeness in a particular society is different from other societies. Language politeness in folk language (folk speech) as part of the regional culture in this archipelago is one manifestation of oral tradition that should be grown. It is intended to rediscover the ancestral guidelines contained in the language-speakers' culture. Through the oral tradition of folk language, can be extracted local wisdom contained in the culture speakers of the said language. This can be used as an alternative to answer the nation's current problems. The threat of disintegration which is one of the causes is the loss of the values of language politeness in communicating. It is also possible in the community of Empat Lawang district in South Sumatra.

The distinctive character of the community of Empat Lawang district as a harmonious collective society is the feeling of shame and the maintenance of a strong 'face' image. Feelings of shame and guarding the self image of others so that the atmosphere of harmony awake realized by holding the principle of harmony that aims to maintain society in a harmonious life. Citizens of the Empat Lawang district are accustomed to avoiding conflict by not showing their true desires. Such nature is considered reasonable because the culture of the district community Empat Lawang Kanan more concerned with the atmosphere 
of harmony and harmony. Applying harmonious means eliminating the signs of tension in society or interpersonal so that social relations remain in harmony and work well.

As humans who have been affected and tied to technological developments, the Indonesian people in general and the community district of Empat Lawang in particular have many who forget the rules of communication that includes politeness in communicating. Meanwhile, as the community of Empat Lawang district is required to uphold the politeness and cultural customs that have been ingrained. This tendency if left constantly occurred, it is feared will eliminate the eastern character of the community, especially the community district Empat Lawang. Modesty in communicating as well as one culture, will also help in communicating activities. When considered the description above, it appears that politeness is very influential on the formation of characters in accordance with the purpose of education or character development with local wisdom, derived from the noble values of cultural traditions of the nation. Thus, the understanding of local wisdom as the noble cultural values of the nation, especially the community of Empat Lawang district can be utilized as a source of character formation of the nation. The problem now, how far the local wisdom has been utilized for the formation of nation character.

Cutting (2002: 178) states that language politeness is a linguistic expression that gives people space and shows a friendly attitude to them. According to Brown and Levinson (2006: 315), in every interaction, the participants said do not want his honor disturbed or diusik others. To that end, the speakers do their best to maintain the honor of their interlocutor. At the same time, the participants also tried to prevent his own face from injury. To achieve these objectives, the participants said to try to prevent conflict or conflict in communicating. In an oral communication, this is done by measuring the threat level of an action and trying to reduce that level of threat by realizing the politeness strategies. While Grice (1975: 45-46) argues that a reasonable discourse can occur when between speakers and speakers obey the principle of communication cooperation. The principle of cooperation consists of four conversational maxims (conversational maxim), namely: (1) maxim of quantity (maxim of quantity); (2) maxim of quality; (3) the maxim of relevance; (4) and maxim of manner (maxim of manner).

\section{METHOD}

This research was conducted in Empat Lawang district in January - June 2016. This research has various background. The research background is centered on two types: formal and informal. Selection of both backgrounds is very influential on the use of language including politeness in the language. The formal situation will be different language politeness used with informal situation. For that, the participants said in communicating must understand the situation, events, and communicative actions. The formal activities in this research are centered at the office of National Unity and Political Institution (Kesbangpol), Library Office, Archives and Documentation Office of Empat Lawang District, Pendopo - Lintang Kanan Subdistrict Office, and SMA Negeri 1 Pendopo Barat. While informal activities are centered in Pasar Pendopo, Ruko (rumah toko) Pendopo, Tanjung Raman Village Football Field, Tebing Garden Garden, and community house in Pendopo - Lintang Kanan sub-district in Empat Lawang Regency and share the background of open background and closed background. Open space is in public places such as markets, shophouses, soccer fields, gardens, and community homes. Conversely, on a closed background the researcher's relationship is more familiar because it is characterized as a subject that needs to be closely observed with in-depth interviews. This research is a qualitative research with ethnography method of communication. Communication ethnography is basically a study that attempts to describe the use of language in the context of a particular situation. 
Data collection was done by observation, recording, and interview. Verification of data validity is done by credibility, transferability, dependability, and komfirmabilitas. Data analysis is done by transcribing the recorded data into written form, then analyzed by situation, event, and communicative action. The results showed the following findings:

\section{RESULTS AND DISCUSSION}

Firstly, in this research, the researcher find 2 (two) kinds of word politeness strategy found by society of Pendopo-Lintang Kanan, that is positive and negative politeness strategy. Positive language strategies consist of: (1) strategy 3, intensifying the listener's attention by dramatizing events or facts; (2) strategy 4: using group identity markers: greetings, dialects, or hoses; (3) strategy 8: using joke; And (4) Strategy 11: shows optimism. While the negative language politeness strategy, consisting of: (1) strategy 1, using indirect tututran; (2) strategy 5, pay homage; (3) strategy 6, apologize; (4) strategy 7, using impersonal forms; And (5) strategy 10, claiming self-indebtedness.Positive language politeness strategies fit Brown and Levinson models that critics including FTAs intrinsically threaten the positive face of the speaking partner. FTA criticism needs to be done with courtesy to reduce its threat of power. In fact, the criticisms were expressed with courtesy. In addition, language politeness strategies involve speakers and partners in the activity. While negative language politeness strategy in accordance with the model of negative politeness Brown and Levinson that the realization of negative politeness to put pressure on negative face partners said not always appropriate data of this study. Both FTA self-defense in the form of rejection and FTA explanation as described above not only injure negative face but also positive face partners said, namely the desire for self-esteem is not injuredand the desire to be accepted as a group of others can be met.

Secondly, in this research, the researcher finds 4 (four) maxim form of cooperation principle in politeness of language of Pendopo-Latitude Right, covering: (1) maxim of quantity; (2) the maxim of quality; (3) the relevance maxim; And the way maxim. The results showed that Grice cooperative principle acts to manage every speech spoken by the participants. In this study, the researcher explained that the application of Grice cooperation principle in formal and informal conversation in Empat Lawang district. Implementation of the principle of cooperation, researchers study it based on the speech spoken by speakers in the formal and informal situation. Based on formal and informal analyzes it was found that speech participants applied and violated Grice's cooperation principles.

Thirdly, in this research, the researcher found the politeness of language function of the regency of Empat Lawang, covering: (1) question function; (2) offer function; (3) command or order functions; And (4) refuse function. The findings indicate that the actual speech activity in the formal and informal situation of the three forms of speech is not always manifested as to the meaning it carries. Speakers as participants who are proactive and have responsibility for the achievement of communication purposes using language as a form of expression in conveying their desires. But not always obey the conventional rules which states that the declarative form meaningful proposition, meaningful imperative form of command, and interrogative form to ask or request so that the function of language politeness can be seen from the form of delivery that is directly and indirectly when associated with the scale of politeness Leech then the more direct The meaning of a speech is more tidahlah speech it. Conversely, the more indirect the meaning of a speech the more courteous the utterance. Therefore, it can be said that the three utterances are not in line with the form of construction but determined by the context of the speech situation that accompanies and behind the speech. The speech situation in question is the speaker and the speech partner, the context of the speech, the purpose of the speech, the speech as a form of speech or 
activity, and utterance as a verbal action product. This is in line with Huang's opinion that one aspect to be considered for the purpose of politeness is the state or situation of the conversation.

Fourth, viewed from the aspects of culture, politeness language community Pendopo-Latitude Right in the form of verbal and nonverbal communication. The cultural aspects of verbal communication are accents like the word 'bee' and the use of greetings, such as 'bapang', 'ndung', 'khaban with', 'bicik'. While the cultural aspects of nonverbal communication include: kinesik and kenistetik. Both of these have important roles in communication.

According to Brown and Levinson models, critics including the FTA are intrinsically threatening the positive face of the talk partners. FTA criticism needs to be done with courtesy to reduce its threat of power. In fact, the criticisms were expressed with courtesy.

In addition, language politeness strategies involve speakers and partners in the activity. Speakers use our "us" person to replace the word "you" who can assume a partnership and can alleviate the FTA. When leaving the place must be a good way too. The above notion is not in line with Brown and Levinson modeling concepts which emphasize that the higher the threat, the more indirectly the language is used. In addition to a positive politeness strategy, Liturgy societal language of the Pendopo Lintang also consists of five forms of negative politeness strategies used by speakers to reduce the potential for negative face. Brown and Levinson stated that negative politeness has an orientation to avoid conflict. The realization of negative politeness reflects a speaker's attempt to respect the other's freedom of speech to act and his desire not to be burdened. If an FTA is to be done and that freedom must be harassed, efforts should be made to reduce the level of disturbance

The concept of negative politeness above is not always applicable to this research data. Brown and Levinson's remarks that the realization of negative politeness will not or only slightly interfere with the freedom of others to act and is fully supported in this study. For example, the speaker's speech contains a directive acting act asking for a potentially threatening, negative face to the said partner.

The above description does not show Brown and Levinson negative politeness models that the realization of negative politeness puts pressure on the negative face of the said partner does not always fit this research data. Both FTA self-defense in the form of rejection and FTA explanation as described above not only injure negative face but also positive face partners said, namely the desire for self-esteem is not injured and the desire to be accepted as a group of others can be met.

Principles of Cooperation in Public Speech of the Regency of Empat Lawang The results showed that Grice cooperation principle acts to manage every speech spoken by the participants said. In this study, the researcher explained that the application of Grice cooperation principle in formal and informal conversation in Pendopo Empat Lawang district. Implementation of the principle of cooperation, researchers study it based on the speech spoken by speakers in the formal and informal situation. Based on formal and informal analyzes it was found that speech participants applied and violated Grice's cooperation principles.

The description of the maxims of the way in the formal and informal conversations of the rightlumbar Pendopo community related to the way speakers said. This means achieving the maxim of the way in formal and informal conversations if the speakers and the spokesperson have had a conversation in a predetermined way that is not vague, not taxa, and not excessive. Thus the speaker is able to interpret the words used by his or her partners on a taxi based on usage contexts. Wijaya argued that the coercion 
would not arise if the cooperation between the participants was always based on careful observation. In formal and informal conversations have applied the maxim way because every speech is spoken well and in accordance with the principle indicators of cooperation proposed by Grice.

Community Speech Functions of Empat Lawang RegencyIn relation to the language courtesy function of Empat Lawang regency both formal and informal situation, the result of the research shows the description of the function in question includes: (1) the questioning function; (2) offer function; (3) command / order function; And (4) refuse function. The formulation of the above functions is done in the form of interrogative, imperative, and declarative speech. The use of these three speeches is not systematically patterned in any variation of speech acts when delivered by speakers and speech partners. Diversification of speech acts (speech) functions expressed by speakers in speech is sometimes delivered directly and indirectly.

The findings indicate that the actual speech activity in the formal and informal situation of the three forms of speech is not always manifested as to the meaning it carries. Speakers as participants who are proactive and have responsibility for the achievement of communication purposes using language as a form of expression in conveying their desires. But not always obey the conventional rules which states that the declarative form meaningful proposition, meaningful imperative form of command, and interrogative form to ask or request so that the function of language politeness can be seen from the form of delivery that is directly and indirectly when associated with the scale of politeness Leech then the more direct The meaning of a speech is more tidahlah speech it. Conversely, the more indirect the meaning of a speech the more courteous the utterance. Therefore, it can be said that the three utterances are not in line with the form of construction but determined by the context of the speech situation that accompanies and behind the speech. The speech situation in question is the speaker and the speech partner, the context of the speech, the purpose of the speech, the speech as a form of speech or activity, and utterance as a verbal action product. This is in line with Huang's opinion that one aspect to be considered for the purpose of politeness is the state or situation of the conversation.

Speech Language Based on Cultural Aspects of the Community of Empat Lawang Regency. The community of Empat Lawang district in interacting to attempt to use moderate sound pressure is sometimes high. In addition, there is a special emphasis on a word by adding the word "bee". In accordance with the rules in the formal activities, the addition of words containing the elements of language language inteference into the Indonesian language should not be done because it is not in accordance with the context. But speakers retain the cultural aspect so that the form of accent as above is often used even though the activity is formal. However, such habits can make a speechless companion do not understand the intended purpose if they do not have specific knowledge about the use of the word. Based on interviews with resource persons revealed that the occurrence of interference caused by the influence of natural dialect that is done naturally.

In accordance with the findings of the researcher that one of reciprocal endeavors conducted by speakers and partners said in minimizing face threats other than the use of indirect speech acts is the use of speech dicarkahi by choice of diction and variation of informal speeches sosiocultural background of the community district Empat Lawang as a form of language politeness. Variations of speech refers to activities or activities in interacting both formal and informal situations that are directly governed by rules or norms for the use of speech. Kartomiharjo says that speech variation is a reflection of social and cultural factors and is bound by rules and norms. As the results of research that has been done show that 
people speak Javanese language often use variations of Javanese speech in memarkahi Indonesian language used, including the use of greetings,

There are two greeting functions according to Chaika. First the greeting is used as power and solidarity. Second, greetings can be repeated over and over in a conversation to strengthen intimacy and power relationships between speakers and partners. Chaika's opinion is in line with Kridalaksana opinion that the greeting system is a system that binds elements of language that marks the difference in status and role of participants in language communication.

In connection with this Pranowo argued that speakers should use the word $\mathrm{Mr} / \mathrm{Ms}$ to call the second adult or other greeting as a choice of words (diction) that reflect the sense of courtesy. Leech argues that the scale is very gayut with politeness, the scales that depart from Brown and Gilman explanations. The scales determine the choice between the familiar pronoun greeting with respectful pronouns.

\section{CONCLUSION}

Based on the above findings and discussion, it can be concluded as follows: Empir Lawang community empowerment strategy applied 2 (two) strategy that is positive politeness strategy and negative politeness strategy. The form of positive politeness strategy in the society of Empat Lawang district are: (1) intensifying the listener's attention with dramatizing the event or fact; (2) using group identity markers, greetings, dialects, or slang; (3) using joke; And (4) shows optimism. While the negative politeness strategy for community speech district Empat Lawang, namely: (1) using indirect speech; (2) pay homage; (3) apologize; (4) wearing impersonal forms; And (5) claiming to be indebted.

The principle of cooperation in politeness of language community of Empat Lawang district both in formal and informal situation have applied Grice cooperation principle, that is (1) application of maximize quantity; (2) quality; (3) relevance; And (4) ways. These four kinds of maxims have been applied in various situations so that communication runs smoothly. Although the community of Empat Lawang district has applied maxim, but from so many speeches there are also maximal violations. This happens because of the speaker's ignorance in speaking.

The courtesy function of the community in Empat Lawang regency either formal or informal situation is conveyed by giving directly or indirectly as a form of self expression in the functioning of the language as a medium to achieve the purpose of communication. Giving the intended function is: (1) the function of asking; (2) offer function; (3) command / order function; And (4) refuse function.

Perseverance in terms of cultural aspects of verbal communication courtesy language Societal Pendopo-Latitude Right in the form of verbal and nonverbal communication. The cultural aspects of verbal communication are accents like the word 'bee' and the use of greetings, such as 'bapang', 'ndung', 'khaban with', 'bicik'. While the cultural aspects of nonverbal communication include: kinesik and kenistetik. Both of these have important roles in communication.Thus, the right societal language of right-hinged Pendopo has adopted a language-based politeness strategy, applying the principles of cooperation, carrying out the functions of politeness and taking into account cultural aspects. Thus, the politeness of the language community of Empat Lawang district needs to be instilled to the successor's genaration. 


\section{REFERENCES}

Brown, Penelope \& Stephen C. Levinson. "Politteness: Some Universal in Language Usage." In The Discourse Reader: Introduction.Second Edition. Jaworski, Adam and Nikolas Coupland (Eds.). London: Routledge, 2006.

. Politeness: Some Universal in Language Usage. Cambridge: Cambridge University Press, 2000.

Cutting, Joan. Pragmatics and Discourse. London: Routledge, 2008.

Leech, Geoffrey. Prinsip-prinsip Pragmatik, Terjemahan M.D.D. Oka. Jakarta: Universitas Indonesia, 1993.

. The Pragmatics of Politeness. Oxford:Oxford University Press 2014.

Watts, Richard J. Politeness. Cambridge: Cambridge University Press, 2003.

Yule, George. Pragmatics. Oxford, New York: Oxford University Press, 1996. 